\title{
Penggunaan Metode Bervariasi Dalam Meningkatkan Hasil Belajar Siswa Kelas Iv Pada Mata Pelajaran Matematika Tentang Bilangan Romawi Di Sd Inpres 1 Kabupaten Sorong

\author{
( Sebuah Studi di SD Inpres 1 Kabupaten Sorong )
}

\author{
Moch. Zainuri, A.Ma.Pd \\ E-mail : moch.zainuri67@gmail.com
}

\begin{abstract}
The improvement of students' learning result depends on the learning method and learning props. That was why, this research aimed at finding whether the use of variation methods could improve the learning result of students of IV grade in the Mathematics subject on the material of roman numerals at SD Inpres 1 Sorong Regency. This research is a classroom action research which consisted of 2 cycles. The subject of this research was students of IV grade at SD Inpres 1 Sorong Regency with the total number of 24 students that consisted of 12 females and 12 males. The techniques of collecting data used were observation, interview, documentation and test. After applying 2 cycles, the learning objectives could be obtained on the $2^{\text {nd }}$ cycle, that was completeness score improved up to $25 \%$ on the process assessment and $75 \%$ on the formative test. It means that learning completeness had improved above the standard of Minimum Completeness Criteria (KKM) at SD Inpres 1 Sorong Regency.

Keywords: Variation method, learning result, mathematics, roman numerals, SD Inpres 1 Sorong Regency
\end{abstract}

Abstrak: Peningkatan hasil belajar siswa sangat tergantung pada metode pembelajaran dan alat peraga. Oleh karena itu, penelitian ini bertujuan untuk mengetahui apakah penggunaan metode bervariasi dapat meningkatkan hasil belajar siswa Kelas IV pada Mata Pelajaran Matematika tentang Bilangan Romawi di SD Inpres 1 Kabupaten Sorong. Jenis penelitian ini adalah penelitian tindakan kelas yang menggunakan 2 siklus. Subjek penelitian adalah siswa kelas IV SD Inpres 1 Kabupaten Sorong yang berjumlah 24 siswa, terdiri dari 12 siswa laki-laki dan 12 siswi perempuan. Pengumpulan data menggunakan observasi, wawancara, dokumentasi dan tes. Setelah dilakukan penelitian menggunakan 2 siklus, tujuan pembelajaran dapat tercapai pada siklus ke II dengan ketuntasan mencapai $25 \%$ pada hasil penilaian proses dan pada tes formatif meningkat menjadi $75 \%$, yang berarti ketuntasan belajar sudah meningkat diatas standar Kriteria Ketuntasan Minimal (KKM) belajar siswa di SD Inpres 1 Kabupaten Sorong.

Kata kunci: Metode bervariasi,hasil belajar, matematika, bilangan romawi, SD Inpres 1 Kabupaten Sorong

\section{Pendahuluan}

Menurut Mulyasa (2009:95) Pendidikan merupakan sesuatu hal yang sangat perlu dan penting untuk dijadikan suatu kebutuhan manusia. Dalam pelaksanaan pendidikan, penggunaan metode yang lebih dari satu metode memang sangat diharapkan dapat mencapai tujuan yang telah ditetapkan, dengan demikian penggunaan multi metode dalam suatu pengajaran memanglah sangat penting dan perlu. Metode / cara yang digunakan harus yang baik dan sesuai dengan keadaan. 
Menurut Muhsetyo, dkk (2007:1.26) Pembelajaran Matematika merupakan proses pemberian pengalaman belajar kepada peserta didik melalui serangkaian kegiatan yang terencana sehingga peserta didik memperoleh kompetensi tentang bahan matematika yang dipelajari. Struktur yang ada dalam matematika sangatlah sistematis, mulai dari matematika tingkat dasar (hitungan) sampai pada matematika terapan atau aplikasi terhadap ilmu yang lain serta pengembangannya. Penguasaan bilangan akan besar pengaruhnya dalam mempelajari matematika.

Keberhasilan siswa merupakan keberhasilan guru juga dalam mengajar, maka dari itu diperlukan kemampuan guru dalam menggunakan setiap metode yang dipilih dan itu tergantung pada pemahaman serta kreativitas guru.

Pada saat Prose pembelajaran dikelas IV SD Inpres kayumerah semester dua tahun ajaran 2016 mata pelajaran matematika tentang bilangan romawi, guru hanya menggunakan metode ceramah saja tidak ada alat peraga yang dijadikan media pebelajaran. Akhirnya saat melakukan tes tertulis hasil belajar siswa tidak memuaskan. Mata pelajaran matematika yang mendapat nilai dari KKM 65 keatas hanya 3 siswa dari 24 siswa dan dari 21 kurang dari KKM 65 dari 24 siswa.

Ternyata pembelajaran di kelas IV kurang memuaskan hasilnya. Melihat realita di atas bahwa proses pembelajaran selama ini yang belangsung di kelas belum memenuhi harapan guru, siswa dan sekolah. Hala ini karena guru dalam menyampaikan materi hanya menoton saja sehingga membuata siswa bosan.

Berdasarkan beberapa alasan tersebut diatas peneliti tertarik untuk mengkaji tentang Penerapan Metode Bervariasi Dalam Meningkatkan Hasil Belajar Siswa Kelas IV SD Inpres 1 Kabupaten Sorong Pada Mata Pelajaran Matematika Tentang Lambang Bilangan Romawi.

\section{Metode Penelitian}

\subsection{Desain Penelitian}

Penelitian ini merupakan penelitian tindakan kelas. Desain penelitian tindakan kelas secara umum mencakup empat langkah, yaitu : 1) perencanaan; 2) Tindakan atau pelaksanaan; 3) observasi atau pengamatan; 4) refleksi. Keempat langkah ini dilakukan secara berurutan dan di identifikasi menjadi sebuah siklus. Dari beberapa tahapan ini gunakan untuk mengetahui perkembangan perubahannya dan dapat melakukan perbaikan disiklus berikutnya.
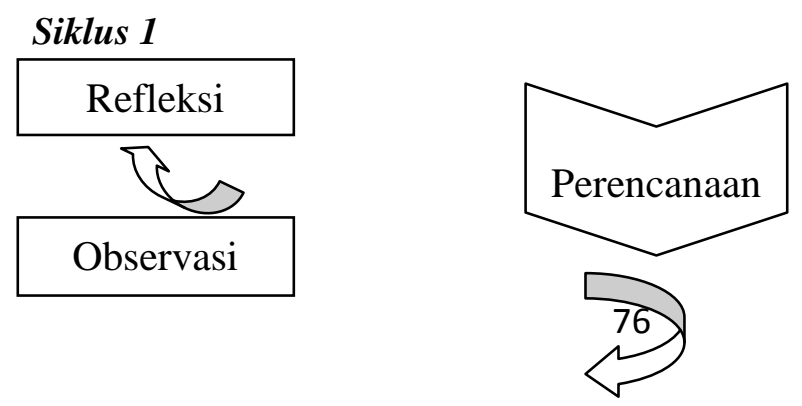
Siklus 2

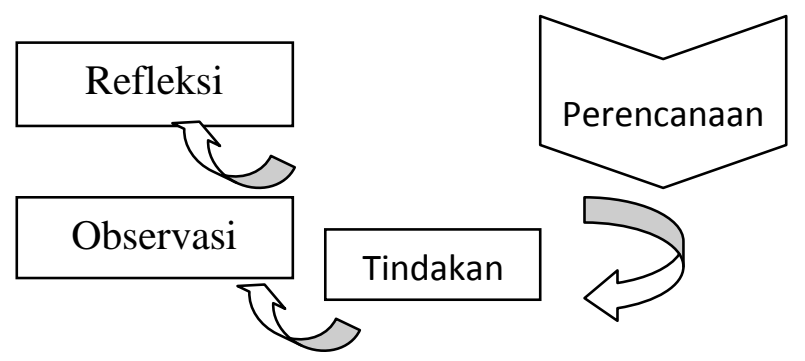

Gambar 1. Arikunto, dkk dalam Mulyasa (2011)

\subsection{Subjek Penelitian}

Kelas yang dijadikan subyek penelitian ini adalah siswa kelas IV SD Inpres 1 Kabupaten Sorong yang berjumlah 24 orang dengan perbandingan 12 siswa perempuan dan 12 siswa laki-laki. Alasan peneliti memilih kelas IV sebagai subyek penelitian kali ini karena dalam materi Matematika tentang "Lambang Bilangan Romawi" diajarkan pada kelas ini pada semester dua.

\subsection{Lokasi dan Waktu Penelitian}

Penelitian dilaksanakan di SD Inpres 1 Kabupaten Sorong yang terletak Distrik Aimas Kabupaten Sorong. Sementara waktu penelitian dimulai dari perencanaan penelitian ini berlangsung hingga akhir penelitian sampai penulisan laporan penelitian. Dalam menyelesaikan laporan ini memerlukan waktu kurang lebih 2 bulan. Dimulai pada bulan Maret hingga bulan April 2016.

\subsection{Teknik Pengumpulan Data}

Untuk memperoleh data-data dari lapangan, penulis menggunakan beberapa teknik pengumpulan data. Teknik yang digunakan dalam penelitian ini adalah observasi, tes, wawancara dan dokumentasi.

\subsection{Teknik Analisis Data}

Data hasil pengamatan aktivitas guru dan siswa selama pembelajaran dihitung dengan menggunakan persentase (\%) sebagai berikut :

$$
\text { Setiap aktivitas }=\frac{\text { Jumlah skor aktivitas yang muncul }}{\text { Skor maksimal aktivitas seluruhnya }} \times 100 \%
$$

\section{Hasil Penelitian dan Pembahasan}




\subsection{Hasil Penelitian}

\subsubsection{Pra-siklus}

Berdasarkan hasil penelitian serta latar belakang masalah pada kegiatan prasiklus hasil belajar siswa sangat rendah. Hal ini terjadi karena kesiapan siswa yang belum maksimal dan penjelasan guru yang sukar dipahami oleh siswa adapun hasil penelitian prasiklus dapat dilihat pada tabel berikut.

Tabel 1. Persentase hasil belajar siswa pada prasiklus

\begin{tabular}{lccc}
\hline \multicolumn{1}{c}{ Kriteria } & Rentang nilai & Jumlah siswa & Presentase \\
\hline Sangat tinggi & $90-100$ & 0 & $0 \%$ \\
Tinggi & $75-89$ & 2 & $9,1 \%$ \\
Sedang & $65-74$ & 6 & $9,1 \%$ \\
Rendah & $50-64$ & 5 & $45,4 \%$ \\
Sangat rendah & $0-49$ & 11 & $36,4 \%$ \\
& Jumlah & 24 & $100 \%$ \\
\hline
\end{tabular}

Dari tabel di atas dapat diambil kesimpulan bahwa hasil belajar pada siswa kelas masi sangat rendah dikatakan masi sangat rendah karena banyak siswa yang mendapatkan nilai 0-49 sebanyak 11siswa atau 36,4 \% katagori sangat rendah 50-64 sebanyak 5 siswa atau 45,4 \% katagori rendah 65-74 sebanyak 6 siswa atau 9,1\% kategori sedang 75-89 sebanyak 2 siswa atau 9,1\% kategori tinggi sedangkan nilai 90-100 tidak ada.

Berdasarkan hasil belajar prasiklus dapat dibuat grafik sebagai berikut

Gambar 2. Grafik Hasil Siswa Prasiklus

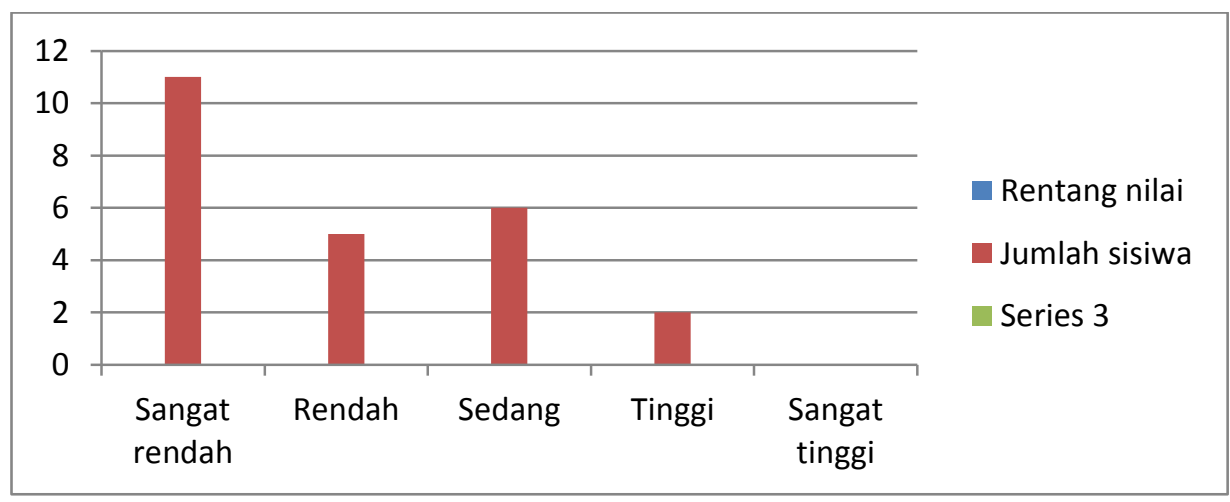

Berdasarkan dari tabel dan grafik analisis nilai belajar prasiklus diperoleh data 11 siswa dengan prosentase 36,4\% mendapat nilai sangat rendah, 5 siswa dengan prosentase 45,4\% mendapat nilai rendah, 6 siswa dengan prosentase $9.1 \%$ mendapat nilai sedang, dan hanya 2 siswa dengan prosentase $9,1 \%$ mendapat nilai tinggi. Sedangkan yang mendapat nilai sangat tinggi tidak ada dengan prosentase 0\%. Dari 
data tersebut dapat diartikan bahwa hasil belajar belum tercapai sepenuhnya,untuk itu perlu diadakan perbaikan pembelajaran. Perbaikan pembelajaran yang akan dilakukan untuk menindak lanjuti adalah 2 siklus perbaikan yang terdiri dari siklus I dan siklus II yang akan diuraikan selanjutnya.

Tabel 2. Persentase hasil belajar siswa pada siklus I

\begin{tabular}{lccc}
\hline \multicolumn{1}{c}{ Kriteria } & Rentang nilai & Jumlah siswa & Presentase \\
\hline Sangat tinggi & $90-100$ & 2 & $10.00 \%$ \\
Tinggi & $75-89$ & 3 & $10.00 \%$ \\
Sedang & $65-74$ & 4 & $9,1 \%$ \\
Rendah & $50-64$ & 7 & $40.6 \%$ \\
Sangat rendah & $0-49$ & 8 & $30.3 \%$ \\
\hline & Jumlah & 24 & $100 \%$ \\
\hline
\end{tabular}

Dari tabel diatas dapat diambil kesimpulan bahwa hasil belajar pada siswa kelas IV masih rendah, dikatakan masih rendah karena masih ada siswa yang mendapat nilai 0-49 sebanyak 8 siswa atau 30,3\% katagori sangat rendah,50-64 sebanyak 7 siswa atau 40,6\% katagori rendah, 65-74 sebanyak 4 siswa atau 9,1\% kategori sedang, 75-89 sebanyak 3 siswa atau 10,00\% kategori tinggi, 90-100 sebanyak 2 siswa atau 10,00 kategori sangat tinggi.

Tabel 3. Persentase hasil belajar siswa pada siklus II

\begin{tabular}{|c|c|c|c|}
\hline Kriteria & Rentang nilai & Jumlah siswa & Presentase \\
\hline Sangat tinggi & $90-100$ & 5 & $20,4 \%$ \\
\hline Tinggi & $75-89$ & 6 & $20,4 \%$ \\
\hline Sedang & $65-74$ & 9 & $39,2 \%$ \\
\hline Rendah & $50-64$ & 2 & $10,0 \%$ \\
\hline Sangat rendah & $0-49$ & 2 & $10,0 \%$ \\
\hline \multicolumn{2}{|c|}{ Jumlah } & 24 & $100 \%$ \\
\hline
\end{tabular}

Dari tabel di atas dapat diambil kesimpulan bahwa hasil belajar pada siswa kelas IV sudah ada peningkatan di katakan peningkatan karena siswa yang mendapat nilai 0-49 hanya 2 siswa atau 10.0\% kategori sangat rendah, 50-64 sebanyak 2 siswa atau 10,0\% kategori rendah, 65-74 banyaknya siswa 8 siswa atau 39,2\% kategori sedang, 75-89 hanya 6 siswa atau 20,4\% kategori tinggi, dan 90-100 sebanyak 5 siswa atau 20,4\% kategori sangat tinggi. 


\subsection{Pembahasan}

Hasil belajar tentang bilangan romawi pada siswa kelas IV pada siklus I yang memiliki kriteria ketuntasan minimal (KKM) sebanyak 9 siswa dari 24 siswa dengan prosentase 29,1\% sedangkan siswa yang belum tuntas pada siklus I ini sebanyak 9 dari 24 siswa atau 70,9\% berdasarkan hasil siklus I dapat dibuat grafik sebagai berikut:

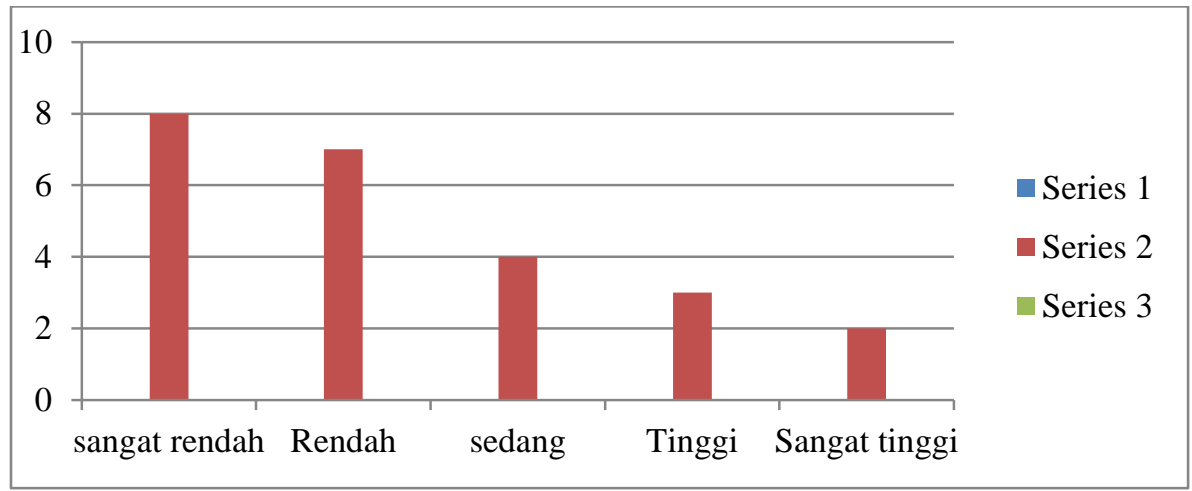

Gambar 3. Grafik Hasil Belajar Siswa Siklus I

Selanjutnya, hasil belajar tentang bilangan romawi pada siswa kelas IV yang memiliki kriteria ketuntasan minimal (KKM) sebnayak 20 siswa dari 24 siswa dengan prosentase $80 \%$ sedangkan siswa yang belum tuntas pada siklus II ini sebanyak 4 siswa dari 24 siswa atau $20 \%$.

Berdasarkan hasil belajar siklus II dapat dibuat grafis sebagai berikut:

Gambar 4. Grafik Hasil Siswa Siklus II

\section{Siklus II}

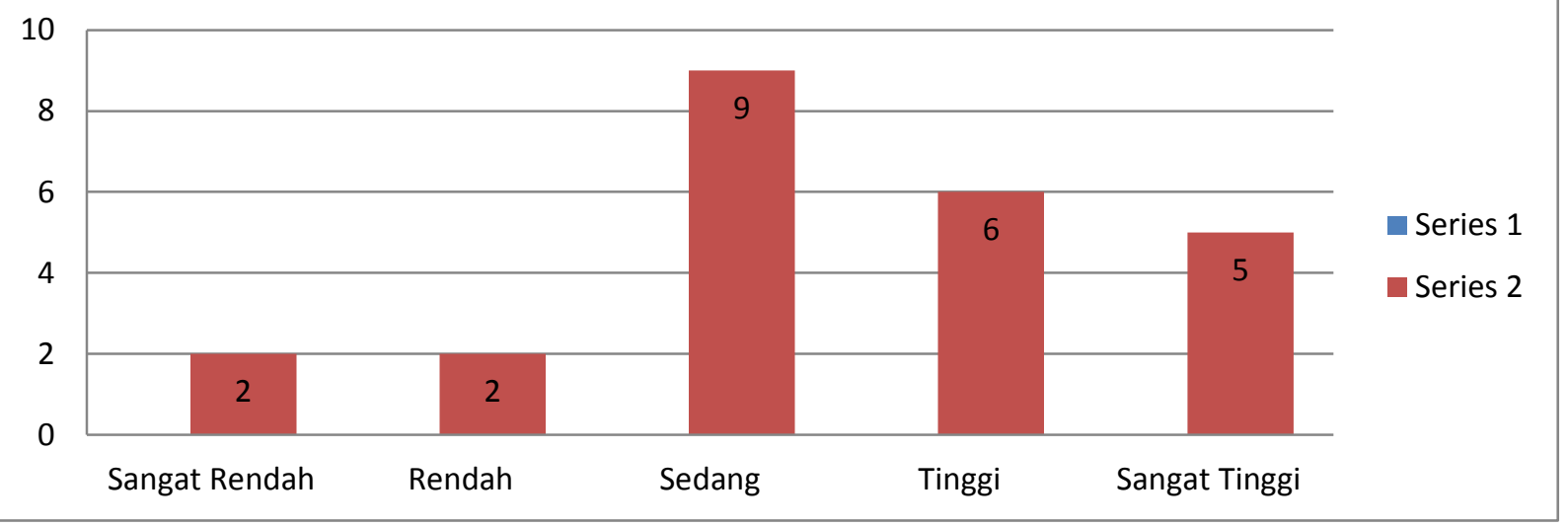


Grafik hasil belajar siswa mata pelajaran matematika pada prasiklus, siklus 1, dan siklus 2 dapat digambarkan sebagai berikut:

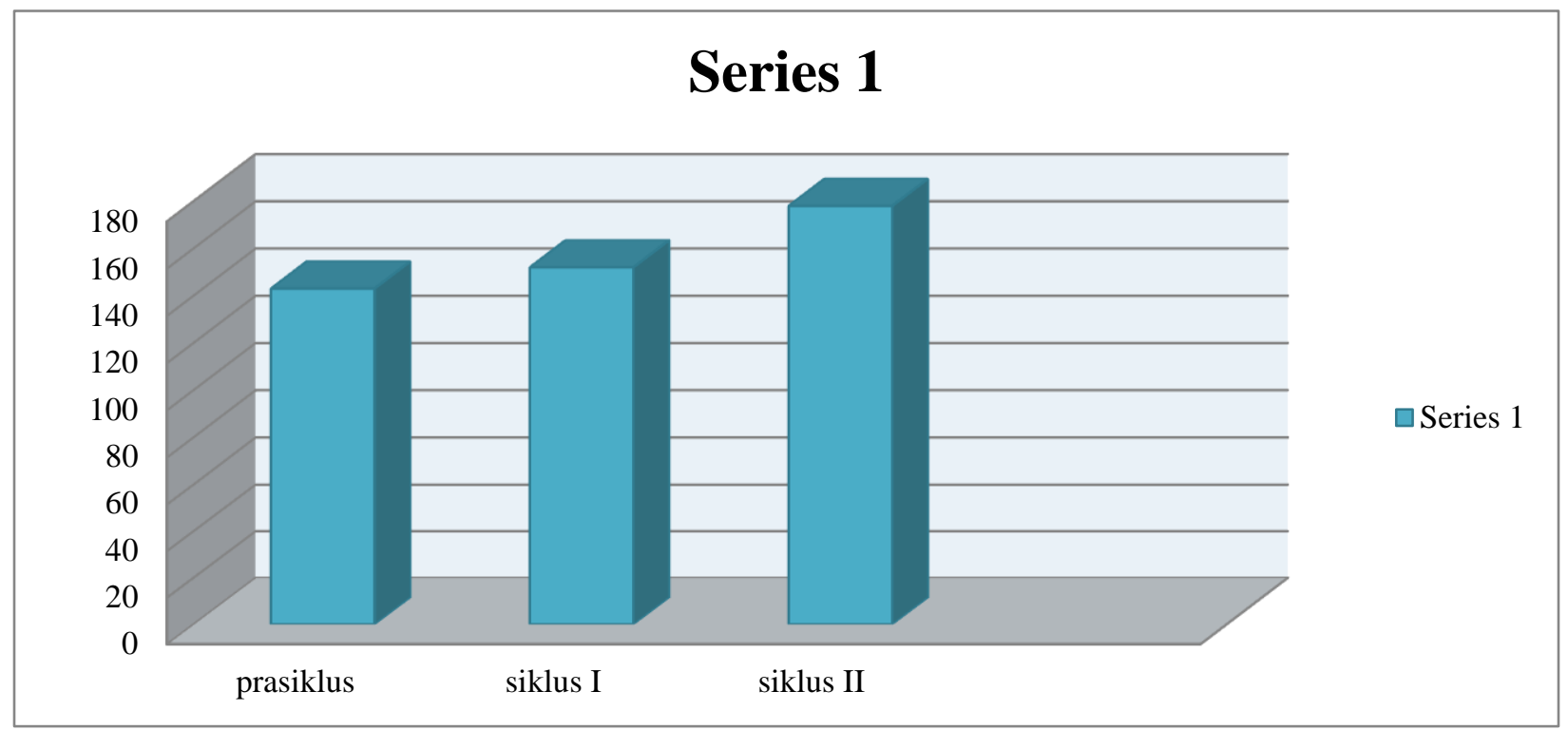

\section{Kesimpulan Dan Saran}

\subsection{Kesimpulan}

Dari hasil analisis pembahasan masalah. Dalam penelitian ini dapat ditarik suatu kesimpulan sebagai berikut:

1) Penggunaan metode bervariasi dalam meningkatkan hasil belajar siswa pada mata pelajaran matematika tentang bilangan romawi, siswa dengan beberapa tahapan. Tahapan yang dimaksud adalah: (a) persiapan, (b) aktivitas belajar mengajar, dan (c) tahap pelaksanaan tindakan.

2) Setelah siswa diberi tindakan sebanyak satu kali (dua siklus), secara berdaur ulang kemampuannya menguasai maupun pemahamannya terhadap materi baik pada mata pelajaran bahasa Indonesia dan ilmu Pengetahuan Alam sangat (terbaik) tercatat lebih dari $75 \%$. Setelah siklus kedua dilaksanakan, yang memperoleh skor rerata $8-7$ sebanyak 18 orang siswa (90,47\%). Artinya, kemampuan dalam penguasaan materi tergolong sangat baik. Sedangkan, siswa yang memperoleh skor rerata 10 - 9 - dan 8 sebayak 18 orang siswa (90,47\%). Artinya, siswa sudah menguasai materi dengan baik 
3) Kesimpulan ini menunjukkan tingkat keberhasilan yang ditandai dengan telah tercapainya indikator keberhasilan penelitian, yakni siswa yang memiliki kemampuan penguasaan materi dan pemahaman sangat baik minimal 75\%. Sementara itu, berdasarkan data yang diperoleh ditunjukkan bahwa siswa yang menguasai materi sudah di atas $70 \%$ yaitu 90,47\%.

\subsection{Saran}

Agar memiliki nilai guna yang optimal, semua hasil penelitian ini harus segera disosialisasikan dan ditindaklanjuti. Terutama yang berhubungan dengan bagaimana memanfaatkan berbagai strategi pembelajaran, salah satunya adalah dengan metode yang bervariasi. Selain itu, guru-guru Sekolah Dasar harus terus menggiatkan pelaksanaan penelitian tindakan semacam ini, sehingga nantinya akan diperoleh berbagai strategi dalam upaya peningkatan kualitas pembelajaran, yang pada akhirnya akan dapat meningkatkan kualitas dan kredibilitas suatu sekolah.

\section{Daftar Pustaka}

A.M, Sardiman. 2005. Interaksi dan Motivasi Belajar Mengajar. Jakarta : PT Raja Grafindo Persada Arsyad, Azhar, 2011, Media Pembelajaran, Rajawali Press, Jakarta

Djamarah, Syaiful Bahri. 1994. Prestasi Belajar dan Kompetensi Guru. Surabaya: Usaha Nasional

Eko, Purwanto. 2010. Hakekat Matematika. www.smansa.sch.id. (online) diakses tanggal 10 Oktober 2012.

Hamalik, Oemar. 2003. Perencanaan Pengajaran Berdasarkan Pendekatan Sistem. Jakarta : PT Bumi Aksara

Hermawan, Asep hery, dkk. 2009. Pengembangan Kurikulum dan Pemblejaran. Jakarta : Universitas Terbuka

Muhaimin, 2001. Paradigma Pendidikan Islam. Bandung: PT Remaja Rosdakarya.

Muhsetyo, Gatot. 2007. Pembelajaran Matematika SD Jakarta : Universitas Terbuka.

Mulyasa. 2011 Parktik Penelitian Tindakan Kelas, Bandung : Remaja Rosdakarya

Majalah Pendidikan . 2011. Hakekat Matematika. www.majalahpendidikan.com (online) diakses tanggal 10 Oktober 2012

Sudijono Anas. 1999. Pengantar Statistik Pendidikan. Jakarta: PT Raja Grafindo Persada

Sugiyono. 2000. Metode Penelitian Administrasi, Bandung : Alfabeta.

Suprijono, Agus. 2009. Cooperatif Learning, Yogyakarta : Pustaka Pelajar

Syah, Muhibbin. 1997. Psikologi Pendidikan, Bandung : Remaja Rosda Karya 